\title{
Analysis of Belgian Public Accounting and Its Compliance with International Public Sector Accounting Standards (IPSAS) 1, 6 and 22
}

\author{
Sabrina Bellanca ${ }^{1} \&$ Julien Vandernoot ${ }^{1}$ \\ ${ }^{1}$ University of Mons, Warocqué School of Business and Economics, Mons, Belgium \\ Correspondence: Sabrina Bellanca, University of Mons, Warocqué School of Business and Economics, Mons, \\ Belgium. E-mail: Sabrina.Bellanca@umons.ac.be
}

Received: December 6, 2012

Accepted: January 22, 2013

Online Published: April 23, 2013

doi:10.5539/ijbm.v8n9p122

URL: http://dx.doi.org/10.5539/ijbm.v8n9p122

\begin{abstract}
Belgian public accounting, which is continuously evolving, has to meet international standards. The aim of this paper is to describe the current Belgian public accounting systems and to analyze their compliance with IPSAS 1,6 and 22, key points of modern accounting.

We first describe the development of Belgian public accounting since 1846. We then focus on the 2003 accounting reform, and more specifically its content and its triggering factors. The level of implementation of this reform in the different Belgian public entities is then studied. We also make a presentation of IPSAS standards and a list of factors that contribute to or hinder their adoption, followed by an assessment of the current state of their implementation in the world. Finally, we evaluate the compliance of Belgian public accounting with IPSAS 1, 6 and 22. We conclude that the implementation of the 2003 accounting reform as well as the compliance with IPSAS standards vary greatly from one entity to another. In Belgium, public accounting is being modernized but IPSAS do not seem to interest public authorities. Indeed, although accrual accounting is more and more used in public entities, IPSAS have disadvantages and are still incomplete to meet the requirements of public sector.
\end{abstract}

Keywords: public accounting, accounting reform, accounting harmonization, IPSAS, new public management

\section{Introduction}

The Belgian public accounting system has been modified several times since the law of 15th May 1846 on State accounting. At first, the public accounting system only consisted of budgetary accounting but it then evolved and now consists of two parts: budgetary accounting and general accounting inspired by those used by the private sector. Such a system has the advantage of providing more information about the financial and economic situation of public entities and of being more accurate, which enables us to estimate among other things public property and public debt. At the same time as this national evolution there has also been a modernization of accounting at the international level through the introduction of the International Public Sector Accounting Standards (IPSAS) and at the European level through the implementation of the European System of Accounts (ESA). These national and international reforms to modernize accounting tally with the concept of New Public Management (NPM) which aims to give the public sector the benefit of the private sector's most effective management methods. The implementation of international accounting standards makes it possible to harmonize national accounting systems which are considered as very heterogeneous by Benito, Brusca and Montesinos (2007), Brusca \& Condor (2002), Carvalho, Jorge \& Fernandes (2007), the Federation of European Accountants (FEE) (2007), Lüder \& Jones (2003) and Pina \& Torres (2003). The aim of our paper is consequently to describe the development of Belgian public accounting, with particular attention to the 2003 accounting reform, the latest one, and to analyze the current state at each level of power. Then we will situate this system in an international context. We will therefore describe the level of implementation of reforms aimed at adopting an effective accounting system inspired by IPSAS standards, on the basis of the papers of Benito et al. (2007), des Robert \& Colibert (2008) and Christiaens, Reyniers \& Rollé (2010). We will also evaluate the compliance of Belgian public entities with three IPSAS standards of particular interest to them, namely IPSAS 1 "Presentation of financial statements", IPSAS 6 "Consolidated financial statements and accounting for controlled entities" and IPSAS 22 "Disclosure of financial information about the general government sector". 


\section{Belgian Federal Structure}

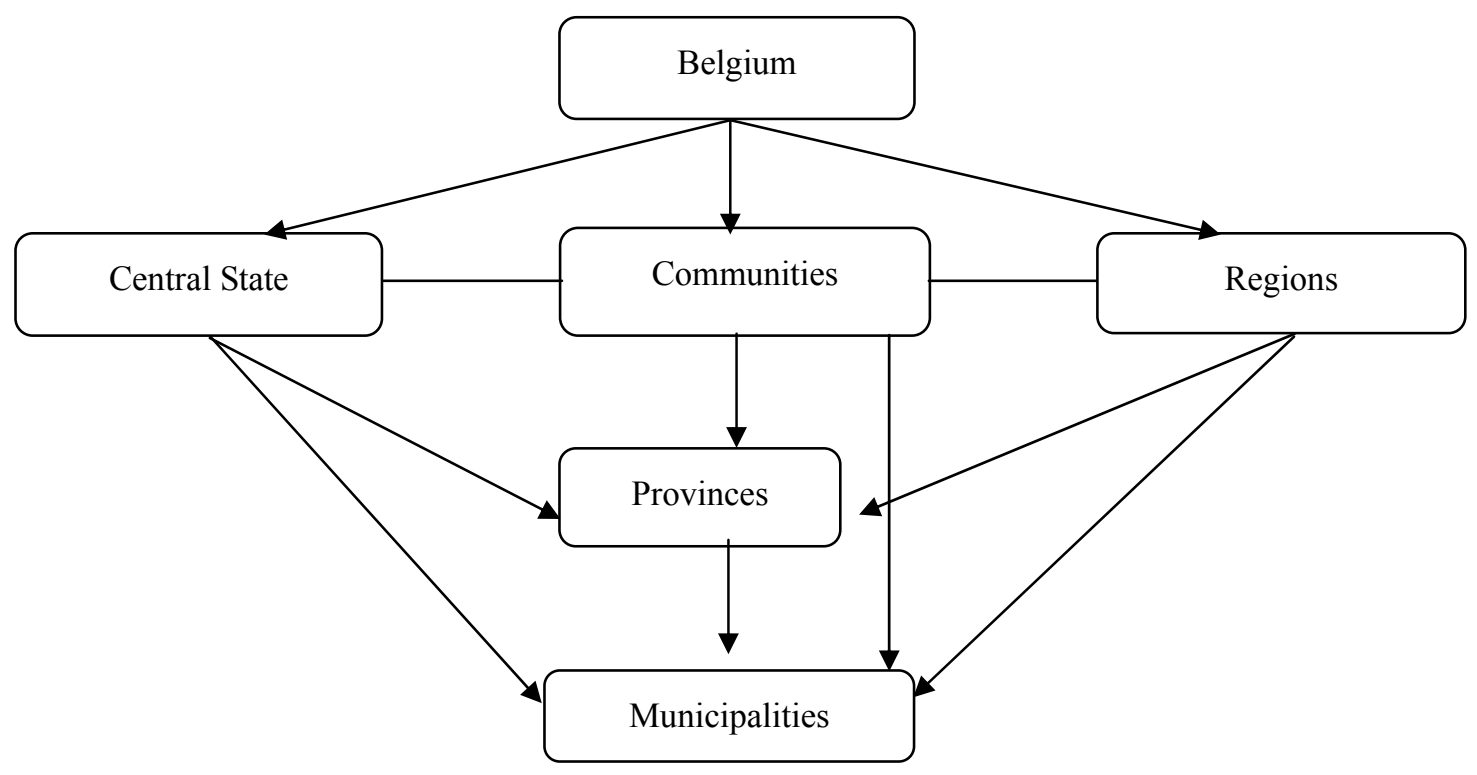

Figure 1. Belgian federal structure

In order to understand the functioning of the Belgian State, it may be useful to refer to the first article of the Belgian constitution which is: "Belgium is a federal State composed of communities and regions". We see that besides the central State which exercises its authority over the whole country, two kinds of federate entities are present, namely communities and regions. These three kinds of entities are equal in rights but have different fields of competence. The three regions, the Walloon region, the Flemish region and the Brussels Capital Region have authority in the fields of economics and territory. The three communities, the Wallonia-Brussels federation, the Flemish community and the German-speaking community are responsible for culture, education, the use of language, etc. The base of the pyramid is made up of local government, namely provinces which are subordinate to higher authorities and municipalities which are the lowest level of power and thus the closest to the citizens.

\section{Evolution of the Belgian Public Accounting System: Some Reforms}

The Belgian accounting system follows from the law of 15th May 1846 on State accounting. It is budgetary accounting, which is a cash basis accounting making it possible to check the receipts and expenses of a year. But this system provides neither a fair view of the patrimony of the public sector entities nor information about debt. As a result, modernization of the public accounting system seemed to be necessary and the needs as regards information and follow-up led to several changes in the law of 15th May 1846.

Among the main changes in the law of 15th May 1846 on State accounting, we can mention the law of 20th July 1921 which created the incurring system of State obligations and the purpose of which is to improve the follow-up of expenses by supervising the different stages of their life cycle. Then, on the 16th March 1954, a law tried to harmonize the budgetary and accounting practices by introducing for the first time a general accounting system consisting of a balance sheet and an income statement. This law does not require public entities to use a chart of accounts but makes reference to the chart of accounts used by private companies. Budgetary accounting remains in force and the receipts and expenses are classified according to their nature in budgetary chapters divided into articles (Desille, 2009). The law of 28th June 1963 requires the charging of expenses on the basis of authorization of expenditure and of receipts on the basis of established entitlements, budgetary operations being split according to an economic classification. Moreover, this law introduces cash account, patrimony change account and of the balance sheet of the central State. Nevertheless the procedure to establish these documents is not clear. Finally, entities without legal personality but with a management independent of the central State can be created: these are "independently-managed government services"which have to establish a patrimonial accounting system and an inventory of patrimony, and State-owned enterprises which have to establish an operating account and a patrimonial situation. Finally, the law of 28th June 1989 modifying the law of 28th June 1963, modifying and completing the laws about State accounting, the law of 16th March 1954 about budget and accounting of organizations of public interest and the law of $31^{\text {st }}$ December 
1986 about provisional allocations created the budget by programmes in the services of the general administration, in order to highlight the relation between the policy and the means used to reach its objectives. Until then, there were 26 budgets of State expenses (one budget per ministry and 9 special budgets) and a budget of receipts. As a result, it was impossible to get a global view of the budgetary situation. The law of 28th June 1989 introduced the principle of a general budget of expenses which groups together all the expenses of the State in a single document. The State budget adopted a new form and four documents had to be introduced in the House of Representatives: the budget of expenses, the budget of receipts, the budget of expenses and the administrative budgets (which were cancelled and integrated into the budget of expenses in 1997). Despite the desire for evolution and several modifications, the organization of State accounting is not fully satisfactory. Indeed, this accounting system makes it possible to compare budgetary previsions and achievements, to check the situation of the treasury and to determine the outstanding commitments and the entitlements to be recovered but some gaps remain, such as the lack of information about the management of the patrimony and the debt and the absence of a long-term forecast. So, a reform of State accounting was necessary to improve significantly the accounting efficiency. The first steps towards accrual accounting, introduced into the law of 1963, did not make it possible to create rules and procedures to provide this kind of information. Accounting technologies are needed in order to get satisfactory accounting in terms of patrimony and budget.

On 15th March 1991, a law on the reform of accrual State accounting and the provincial accounting was adopted. This law generated, on 17th July 1991, the coordinated laws on State accounting. The purpose of this law is to create a standard system of accrual accounting which can be applicable to all public entities integrating all budgetary, financial and patrimonial operations. That way, it is possible to know, thanks to balance sheets, income statements and appendices, the state of each entity's patrimony and the incomes for each financial year. Thus, annual accounts include the budget execution account, an income statement and a balance sheet. Accrual accounting makes it possible to provide information, not only inside public entities but also outside them, enabling all external agents, such as third parties, creditors or citizens, to follow the evolution of the State patrimony. The law of 15th March 1991 also created a Commission for the standardization of public service accounting whose objective is to establish a chart of accounts of State financial, budgetary and patrimonial operations and to set rules concerning budgetary and economic charging. Another important purpose is to adapt the legal texts and rules and regulations in force, particularly the complete revision of State accounting. This commission was replaced, in 2010, by the Public Accounts Committee, which notably informs and advises governments (Central State, Communities, Regions, Joint Community Commission) about public accounting standards and the methods of implementation and the use of the chart of accounts and its compliance with international standards.

The law of 17th July 1975 on private companies accounting and its implementation decrees serves as an example to establish accrual accounting in the public sector. Besides, the creation of a chart of accounts for the public sector follows the example of that of private companies with nevertheless some differences.

Until now, a double accounting system, including budgetary accounting and accrual accounting, has only been implemented in the municipalities (since 1995), in the Public Social Welfare Centers, one per municipality) (since 1997) and police districts (including one or several municipalities) (since 1998) (Khrouz, 2007). The other public entities, which only use budgetary accounting, cannot ensure the transparency of their accounts by providing information about public patrimony. In May 2003, as a result of the law of 15th March 1991, a reform was decided on to solve the problems of the public accounting system.

\section{Reform of 2003}

\subsection{External Triggering Factors}

Factors external to the accounting organization of public entities have also led to a complete modernization of public accounting. First, the European Union expects member States to provide comparable economic information in order to analyze and evaluate the whole economy. To this end, the European Commission created a system of accounting standards, the European System of Accounts, whose latest update was published in 1995 (ESA 95) and whose use is made obligatory by Council Regulation n ${ }^{\circ 2223 / 96}$ of 25th June 1996 on the setting of national accounts. The new system concerns accrual accounting in compliance with the law of 15th March 1991 and requires the charging of operations on the basis of transactions.

The evolution of the institutional organization of the Belgian State has also had an influence. Although communities and regions can freely determine their budgetary and accounting rules (qualified majority law of 16 January 1989), they have to respect general principles shared by all entities and specified by a law. Until these principles have been defined, each entity has to comply with federal accounting rules and each change has 
to take into account the effects on communities and regions.

The "Copernicus" reform (implemented in 1999) is the reform of the Belgian federal Administration which reviews the organizational structure of the federal Administration. It introduces a new management culture, a better human resources management and new work methods. This project showed the need to make the administrative organization of the federal State compatible with budgetary and accounting organization. It therefore constitutes an opportunity to implement accrual accounting in all federal departments.

Finally, IPSAS aim to improve internal control and the transparency of public sector accounts, provide more complete and coherent information about expenses and receipts and make financial statements more coherent and comparable over time and between organizations.

\subsection{Content of the Reform}

Three laws, which are the starting point of a new State budgetary, accounting and financial organization, were adopted within the framework of the reform of May 2003: a law on the budget and the accounting of the federal State, a law which amends the law on the Court of Audit's organization (also eliminating the prior visa of the Court of Audit) and a law on the budget and the accounting of communities and regions (which notably requires each region and community to apply accrual accounting). These laws, the first two of which follow from the law of 15th March 1991 mentioned above, follows the logic of the development of accrual accounting and a chart of accounts for the public sector.

The law of 22nd May 2003 on the organization of the budget and the accounting of the federal State creates a new legal framework on which State accounting will be based. The coordinated laws and their legal provisions are thus repealed for the services of the federal State concerned by the law of 22nd May 2003. This introduces an accrual accounting system, based on transactions and using a chart of accounts. Cash basis accounting and current patrimonial and treasury accounting systems are thus given up. This measure is applicable for all services of federal power and federated entities. These services are:

- General administration, which includes federal public services (called ministries before the "Copernicus" reform).

- Administrative services with self-accounting, which are services without legal personality and a separate patrimony from the State but which have managerial autonomy. They fall under the authority of the Minister who is responsible for the relevant field.

- State administrative bodies, which are non-profit making State services with legal personality, and whose main purpose is to satisfy general interest needs.

- State-owned enterprises, which are State services with a commercial, industrial or financial nature and without legal personality. They are internal dimensions of the federal State and have to comply with accounting and budgetary rules which are common to the internal departments of the federal State but some particularities remain because of their specific character.

\subsubsection{General Accounting}

Concepts of general accounting, developed in the reform of 2003, come from the law of 17th July 1975 on company accounting. Besides, all public entities have to establish a general account, composed of annual accounts, which are the representation of the economic interpretation of the department's activities. They also have to provide the budget execution account, which gives information about the way the budgetary authorizations were used. The annual accounts consist of the balance sheet, the income statement, the summary account of budgetary operations. This account includes receipts and expenses recorded in the budget items of the chart of accounts on the basis of the economic classification and of an appendix. Article 18 of the law of 22nd May 2003 states that the services of the federal State also have to provide an annual report which establishes a link between accounting and their activities. This report gives information about the evolution of financial data.

In terms of accounting technique, general accounting takes precedence over budgetary accounting. Indeed, the general chart of accounts includes all established entitlements, budgetary or not, while budgetary accounting only records budgetary established entitlements. General accounting is made according to a chart of accounts which includes a system of standardized accounts and rules for the recording, the charging and the assessment of operations. The chart of accounts is also applicable to communities, regions and the Joint Community Commission. As said above, accounting is based on transactions, in conformity with the requirements of SEC 95. Thus, operations are recorded in the general accounting documents and charged in the budgetary accounting 
documents on the basis of established entitlements at the moment of transaction and not at the moment of payment, and this applies to both receipts and expenses. In general accounting, an entitlement is established when "its amount has been determined accurately, the identity of the debtor or the creditor is determinable, the obligation to pay exists, the department has a supporting document". In budgetary accounting, this is the moment of the provisional validation for expenses and of the establishment of the entitlement for receipts. Article 7 of the law of 22nd May 2003 also adds that entitlements established during an accounting year or a fiscal year is attached to that year as long as they have been recorded before the 1st February of the next year. Each entitlement established after this date belongs to the next year.

\subsubsection{Budgetary Accounting}

Budgetary accounting remains applicable but the law of 22 May 2003 provides clarifications and changes to existing budgetary practices. Besides, two limiting allocations for expenses are defined, one for commitment and one for payment. The difference between differentiated appropriations and non-differentiated appropriations disappears as well as provisional commitment and carryover of allocations. The law also states that non necessary budgetary commitments have to be cancelled and, at any rate, to the extent of the amount which has not been paid after five years.

\section{Application of the Reform to the Different Levels of Government in Belgium}

Table 1. The current accounting system in the Belgian public services (Note 1)

\begin{tabular}{|c|c|c|c|}
\hline \multirow{2}{*}{\multicolumn{2}{|c|}{ Public sector }} & \multicolumn{2}{|r|}{ Currentaccounting system } \\
\hline & & Budgetaryaccounting & General accounting \\
\hline Federal State & & YES & NO (except for some federal public services) \\
\hline Communities & & YES & NO (being implemented for the German-speaking Community) \\
\hline Regions & & YES & NO (except for the Brussels Capital Region) \\
\hline Provinces & & YES & YES \\
\hline Municipalities & & YES & YES \\
\hline Public & Social & YES & YES \\
\hline \multicolumn{4}{|l|}{ WelfareCenters } \\
\hline Police districts & & YES & YES \\
\hline
\end{tabular}

The law of 22nd May 2003 was supposed to come into force on the 1st January 2004, with however the possibility to postpone it to the 1st January 2005. As for the law of 16th May 2003, its implementation was expected by the 1st January 2004, with also the possibility to postpone this implementation to the 1st January 2007 , at the latest. As shown in table 1, the implementation of these laws has nevertheless been delayed several times for both the federal State and the other levels of government. While municipalities have been using a system which combines budgetary and general accounting since 1995, Public Social Welfare Centers since 1997, police districts since 1998, Walloon and Flemish provinces since 2003, the Brussels Capital Region only implemented the reform in 2006 and the Joint Community Commission in 2007 (some requirements only came into force in 2009). TheGerman-speaking Community published the decree of 25th May 2009 on the implementation of the law of 16th May 2003 and is currently working towards the setting up of the reform. As for the other regions, the communities and the federal State, their accounting is still limited to budgetary accounting (except for some federal public services). A decree on the implementation of the reform for the Walloon Region has recently been adopted.

The implementation of the reform is complex; it requires major changes in accounting practices, the use of new accounting software and therefore new skills that civil servants may not master. Thus, some help is needed and the project "FEDCOM", launched in 2007 and still going on, has been carried out at the federal State level in order to comply with the law of 22nd May 2003. The project "WALCOMFIN" has been launched in order to help the Walloon Region and the French Community to implement the reform.

The evolution of the Belgian accounting system takes place in the context of international accounting since the desire to establish an accrual accounting system based on transactions and double-entry general accounting are key points developed in the framework of the International Public Sector Accounting Standards, IPSAS. So, we 
are going to determine to what extent public entities, which seek to modernize their accounting system, comply with international accounting standards.

\section{IPSAS: Towards Harmonization of Accounting Systems}

\subsection{Introduction}

IPSAS are developed by the IPSAS Board (IPSASB), which was created in 1989 by the International Federation of Accountants (IFAC) and whose purpose is to develop accounting standards in order to improve the quality and the transparency of financial statements of public sector entities all around the world. The aim is to make financial statements comparable from one period to another and from one public entity to another. The application of IPSAS can be a means to imitate practices used in the private sector and, besides, the IPSASB is inspired by the International Accounting Standards for the private sector (IAS/IFRS) to create these norms, while taking into account public sector particularities. This trend, which aims to adapt private sector practices to the public sector, appeared in the 80's, under the name of New Public Management (NPM). New Public Management practices use a market-based approach, focused around flexibility, effectiveness and efficiency (Pina \& Torres, 2003). They have been developed, among other things, to solve the problems of States over-indebtedness, large deficits and the inefficiency of the public sector (Amar \& Berthier, 2008).

New concepts appear with IPSAS: first, cash basis accounting is abandoned in favour of accrual accounting according to which transactions are recorded when they appear and no longer when they are paid (cf. the law of 22nd May 2003 and ESA 95). Concepts (such as asset, liability, net equity, incomes and expenses) are defined more precisely (des Robert \& Colibert, 2008) and the calculation of book value is modified. In this framework, three methods can be considered: the cost, the fair value and the current value (Müller \& Berger, 2009). Moreover, the focus is on performance, accrual accounting and double-entry general accounting (des Robert \& Colibert, 2008). As for financial information, public entities have to publish five financial statements (cf. IPSAS 1) and have to respect principles, such as intelligibility, relevance, true and fair view, comparability, timely reporting and verifiability (IPSASB, 2010).

In order to help public entities to implement these new procedures, IPSASB published a guide, in 2002, with an update in 2004: "Study 14, Transition to the Accrual Basis of Accounting" (IFAC, 2003).

\subsection{Factors Encouraging and Discouraging the Implementation of IPSAS}

Firstly, the key point, at the origin of the creation of international accounting standards, is accounting harmonization, which makes it possible to compare accounting systems more easily all around the world (and in particular for investors such as the International Monetary Fund (IMF) or the World Bank) (Khouatra, 2007). Accounting harmonization also makes it possible to externalize the financial activities of public administrations and can help international organizations to use data from different countries (Benito et al., 2007). Comparability can be realized not only between countries but also within them. Concerning Belgium, for instance, the adoption of IPSAS standards could put an end to accounting systems diversity in the country and thus make it easier to compare financial statements between the different government levels.

Secondly, it is easier for governments to work on IPSASB's knowledge, which is the reference in terms of international accounting standards for the public sector, than to create their own standards to reform their accounting systems. But public entities have a lack of knowledge and little experience in terms of international accounting standards and these can be discouraging factors when it comes to implementing these standards (Christiaens et al., 2010).

Advances in the accounting system used by a public entity will facilitate or not the implementation of IPSAS. A lot of efforts are needed and the process will be long and difficult for entities which do not use a general accounting system or who still use cash basis accounting. Such entities could be discouraged by the work required to comply with international accounting standards. Nevertheless, the use of general accounting, required by IPSAS, can fill in the gaps left by budgetary accounting, providing information about debts, accounts receivable, movable and immovable assets, the revenue of the entity, etc. These are elements of interest since they allow public entities to improve their financial management. In this context, it should be noted that entities which already use general accounting will probably see less interest in adopting IPSAS standards than entities which only use cash basis or budgetary accounting.

One of the reasons for which governments would adopt IPSAS standards is the fact of being able to consolidate financial statements (Christiaens et al., 2010). However, the more complex the entity is (having a lot of entities with various jurisdictions), the more difficult and long it will be to comply with IPSAS and the less States will be disposed to adopt these standards. So, identifying all consolidated entities and their activities and 
consolidating the statement of receipts and expenses will need more time and efforts for more complex public entities. In this framework, IPSAS 6 (cf. infra) develops concepts and methods to consolidate accounts.

Since IPSAS are not obligatory, the motivation to implement them must come from politicians. The focus must be on the support brought by the top management of the entity and by the national or supranational legislative body, which has to provide the entity with time, financial means and the efficient computer tools needed. Training also encourages entities to adopt IPSAS standards. Similarly, it is important to give public entities information about the standards and help to implement them (Christiaens \& Van den Berghe, 2006).

The cost of the implementation of IPSAS is likely to discourage public entities from adopting these standards. Indeed, costs for training, hiring, consultancy, organizational changes, IT investments, and other things, will appear and will change according to the kind of activity of the entity, the way the project is managed, the project teams work and the managerial support.

Finally, IPSAS would make it possible to compare financial information between public and private organizations (Christiaens et al., 2010). Nevertheless, being strongly based on IAS/IFRS, some concepts can seem irrelevant and some procedures difficult to apply, considering the characteristics of the public sector. Indeed, the aim of profit maximization, peculiar to the private sector, does not apply to the public sector, the users of the public sector's financial statements do not have the same needs as the private sector's, accounts of public accounting are different from those used in private accounting and are sometimes peculiar to each entity according to its activity. Thus, organizations will favor budgetary accounting and will be skeptic and reluctant to adopt general accounting. This trend can also be increased by the lack of skills and understanding of people working in the field of general accounting.

\subsection{IPSAS in the World: Various Implementation Levels}

Benito et al. (2007) carried out a study in order to analyze the degree of compliance of accounting standards of different countries with IPSAS standards. On the basis of a survey carried out in 2003 in 30 countries (most of whom are members of the Organisation for Economic Co-operation and Development (OECD)), the authors show that there is an important diversity between the countries studied in terms of implementation of international accounting standards. Indeed, while some countries, such as Australia, New Zealand, Mexico, Portugal, the United Kingdom, the United States and the Netherlands, each have a high compliance index with IPSAS (at local and central levels) (more than 70\%), others, according to the survey, comply very little with these standards, e.g., Argentina, Chile, Norway, France, Italy and Canada (compliance index below 50\%). An intermediate/middle group of countries includes States whose degree of compliance with IPSAS is between 55\% and $65 \%$. These are Finland, Spain and Belgium. As for Austria and Switzerland, the study shows that, at the local level, these countries have compliance indices with IPSAS below 50\% while, at the central level, they are above $55 \%$.

Thus, countries which have the highest compliance indices with IPSAS use integral accrual accounting and provide a lot of information (future obligations, sectorial information, etc.) and consolidated accounts. However, the study reveals that accounting systems vary a lot from one country to another and that they do not globally comply with IPSAS, since the average compliance index is about $60 \%$ for the local and central governments.

In 2008, sources (des Roberts \& Colibert, 2008 and IPSAS, 2008) show that it is possible to classify countries in five categories, according to their degree of progress in the implementation of IPSAS:

- Category 1: Albania, Algeria, Argentina, Bangladesh, Barbados, Brazil, Cambodia, China, Kenya, El Salvador, Fiji, India, Laos, Morocco, Slovakia, Uruguay. These are countries whose governments want to adopt IPSAS and have begun to reform their accounting systems.

- Category 2: Afghanistan, Cyprus, East Timor, Hungary, Indonesia, Latvia, Lebanon, the Maldives, Mongolia, the Netherlands, Norway, Pakistan, Vietnam. Governments of these countries have started a process of implementation of IPSAS and have modified their legislation.

- Category 3: France, Japan, Italy. These countries began to adopt IPSAS in 2006.

- Category 4: South Africa, Azerbaijan, Israel, the Cayman Islands, Uganda, Peru. The adoption of IPSAS has been completed.

- Category 5: Canada, Australia, New Zealand, Great Britain, the United States. These are governments using an accounting system which widely complies with IPSAS.

The study carried out by Christiaens et al. (2010) in 17 countries of the European Union shows that countries/entities which globally comply with IPSAS are Lithuania, Sweden and the United Kingdom (at the 
local and central government levels) and France and Switzerland (only at the central level). At the local level in Belgium, Flanders globally complies with IPSAS. Central governments of the Netherlands and Norway use a cash basis accounting system but plan to adopt IPSAS in the near future. The other countries/jurisdictions studied in the survey use either cash basis accounting (with or without the project of evolving towards accrual accounting), or accrual accounting which does not comply with IPSAS. These include Denmark, Finland, Portugal and Spain (at the local and central levels) and Austria (at the central level). At the local government levels, France, the Netherlands, Norway, Switzerland and Wallonia also use an accrual accounting system which does not comply with IPSAS.

These studies are sometimes contradictory especially for Canada, France, Switzerland and the Netherlands, which are ranked differently in the classifications. It's worth noting that since these studies were carried out at different times, the accounting systems of each country have evolved and the analysis of these systems therefore leads to different results. Moreover, criteria for analysis and classification vary from one study to another, which makes it difficult to compare the results. These enable us to assert that the most advanced countries in terms of implementation of IPSAS are Australia, New Zealand, Canada, the United States, the United Kingdom, Sweden and Mexico. Indeed, accounting systems adopted in these countries widely comply, as well at the local level as at the central level, with IPSAS. As for Belgium, the study of Benito et al. (2007) shows that its compliance index at the local level is about 55\%. However, at the central level, the State only uses cash basis accounting. The survey carried out by Christiaens et al. (2010) puts Flanders among the regions which globally comply with IPSAS, while Wallonia uses an accrual accounting system which does not comply with IPSAS. At the central level, this study also argues that the government uses cash basis accounting, with the project of adopting an accrual accounting system (non-compliant with IPSAS). According to Khrouz (2007), the federal State and regions (except for the Brussels Capital Region) do not comply with IPSAS. Local governments, for their part, comply with IPSAS 1.

Public accounting systems in the world are quite heterogeneous and this diversity has been pointed out in several studies ((Benito et al., 2007; Brusca \& Condor, 2002; Carvalho et al., 2007; FEE, 2007; Lüder \& Jones, 2003; Pina \& Torres, 2003). Thus, some countries actively try to modernize their accounting methods (such as Australia, New Zealand, the United Kingdom and the United States) while others still use "basic" accounting systems without showing any willingness to evolve (Benito et al., 2007; Carlin, 2005; Groot \& Budding, 2008; OECD, 2002; Van Der Hoek, 2005). We can also notice differences concerning the compliance of public accounting systems with IPSAS, which is globally quite weak. These observations also apply for Belgium, since there is no harmonization between the accounting systems of Belgian public entities.

\section{The Case of Belgium}

\subsection{Method}

In the text that follows, we focus on the compliance of Belgian public accounting with three IPSAS, IPSAS 1, IPSAS 6 and IPSAS 22. Two of these standards (IPSAS 1 and 6) were created on the basis of international accounting standards for the private sector. Their interest is obvious to the extent that both the presentation of financial statements (IPSAS 1) and their consolidation (IPSAS 6) are key points of modern accounting. The last one, IPSAS 22, for its part, has been developed to respond to the specificities of the public sector and seems, at first, easier to comply with for public entities. Moreover, this standard has the advantage of referring to the System of National Accounts (SNA 93) and ESA 95 (cf. infra).

So, in order to analyze the compliance of Belgian public accounts with these three IPSAS, we checked the accounting documents published by the different government levels and we verified if the concerned entity provided all the documents or information required by the three IPSAS. As we did not find all the information we needed, we also sent a questionnaire to public entities in order to determine if they respected the requirements of the three IPSAS we studied.

\subsection{Results}

\subsubsection{Application of IPSAS 1: Presentation of Financial Statements}

IPSAS 1 considers that the aim of financial statements is to provide information about the financial situation, the financial performance and the cash flows of an entity. Financial statements must, to be complete, include a statement of the financial situation (which is also called a balance sheet or a statement of assets and liabilities), a statement of financial performance (also called a statement of revenues and expenses, an income statement, an operating statement or a profit and loss statement), a statement of changes in net assets/equity, a cash flow statement, a comparison of budget and actual amounts and explanatory notes. Various principles have to be met 
by entities, namely, fair presentation and compliance with IPSAS, going concern, consistency of presentation, materiality and aggregation, offsetting and comparative information. Finally, IPSAS 1 specifies the structure and content of financial statements.

Regarding compliance with IPSAS 1, and especially the "Components of Financial Statements" part by Belgian public entities, we note that police districts, Public Social Welfare Centers, municipalities, provinces and the Brussels Capital Region provide a balance sheet, an income statement and a comparison of budget and actual amounts, but no statement of changes in net assets/equity. So they are well advanced to comply with IPSAS 1 requirements. However, the federal State, except for some federal public services, the Walloon and Flemish Regions and the French, Flemish and German-speaking Communities do not provide financial statements required by IPSAS 1 . However, the federal State and the German-speaking Community provide a comparison of budget and actual amounts. Therefore, these entities only using budgetary accounting are not in a position to comply with IPSAS 1.

\subsubsection{Application of IPSAS 6: Consolidated and Separate Financial Statements}

IPSAS 6 requires from controlling entities the presentation of consolidated financial statements including the controlled entities. According to this standard, control is the power to govern the financial and operating policies of the controlled entity (power) and the possibility of profiting from the activities of the controlled entity (benefit). The consolidated financial statements must include all the entities controlled by the controlling entity, except for those temporarily controlled. Consolidated financial statements are obtained by combining, line by line, the financial statements of the controlling entity and the controlled entities by adding together like items of assets, liabilities, net assets/equity revenue and expenses.

Concerning the compliance of Belgium with IPSAS 6, it appears that the federal State provides some consolidated budgetary documents, namely the general budget, the general budget of expenses, the budget of receipts. However, accounts of entities controlled by the federal State, namely the public federal services, government services, the federal Police and the Ministry of Defense are not consolidated. Besides, documents linked to general accounting (balance sheet, income statement, appendices) are not produced in a consolidated form.

\subsubsection{Application of IPSAS 22: Disclosure of Financial Information about the General Government Sector}

The implementation of IPSAS 22 is justified by the existence, among other things, of the SNA 93 and the ESA 95 which require from the States to compile financialinformation about the general government sector. The aim of IPSAS 22 is thus to define information that must be provided by the States which decide to disclose information about the general government sector in their consolidated financial statements. In addition to the various remarks about the accounting methods to use, IPSAS 22 lists information about the general government sector which has to be provided by the States:

- $\quad$ Assets by major class, showing separately the investment in other sectors;

- $\quad$ Liabilities by major class;

- $\quad$ Net assets/equity;

- Total revaluation increments and decrements and other items of revenue and expense recognized directly in net assets/equity;

- $\quad$ Revenue by major class;

- $\quad$ Expenses by major class;

- $\quad$ Surplus or deficit;

- $\quad$ Cash flows from operating activities by major class;

- Cash flows from investing activities;

- Cash flows from financing activities.

In Belgium, the accounts of public administrations are annually published by the National Bank. They are supposed to be prepared in compliance with the ESA 95 requirements mentioned above. However, all the information needed to comply with IPSAS 22 is not currently provided in this disclosure. Indeed we only found three out of the nine items listed above in this disclosure, namely the surplus or deficit, the revenue by major class and the expenses by major class. The surplus and the deficit, also called net lending or net borrowing, mean respectively that the national economy provides the rest of the world with resources or receives resources from it. As for revenue and expenses, they are broken down according to the economic classification in order to 
make the transition from budget to national accounts. So, the classification includes ten mean groups. The groups from 0 to 4 relate to current operations, those from 5 to 8 refer to capital operations and the group 9 includes operations related to public debt other than interest charges (Note 2). We were also able to find information about operating surpluses and changes in net assets but that is not enough to comply with IPSAS 22 .

\subsection{Discussion}

This study shows that Belgium currently does not comply with IPSAS 1, 6 and 22. But some encouraging and discouraging factors are to be noted. Thus, the compliance with ESA 95, made obligatory for members States of the European Union, is a first step towards the compliance with IPSAS 22. IPSAS 1 is, for its part, globally adopted at the local level (provinces, municipalities, Public Social Welfare Centers and police districts). However, at other levels, the use of a budgetary accounting system alone is not enough to comply with this standard. As for IPSAS 6, it appears that accounting documents are, to a small extent, published in a consolidated form. Indeed, at the federal level, only some budgetary documents are provided in a consolidated way, which is not the case for the documents about general accounting.

As mentioned above, some factors can explain the non-application of IPSAS in Belgium. Indeed, the introduction of these standards is a process which is costly and time-consuming. The elaboration of the first "IPSAS financial statements", for example, requires a huge workload.

Moreover, this system seems incomplete to meet the requirements of the public sector. Indeed, some characteristics of this sector are not currently treated by IPSAS, such as social benefits (which represent an important part of public expenses), pensions or the historical heritage. So, the decision to move to an IPSAS system does not seem on the agenda because these standards are currently not developed enough.

IPSAS are a complex and abstract system, unlike the cash basis budgetary accounting which is simple to use and to understand. So, officials and elected representatives do not see the need to use IPSAS, and even accrual accounting. Indeed, politicians and parliaments are not currently interested in balance sheet items; they discuss about budget and theirs authorizations.

Nevertheless, in Belgium, public accounting is being modernized and accrual accounting has been used for some years in some public entities. Some requirements of IPSAS are even respected in the more advanced entities. But it is to note that even if some entities use a system that complies with IPSAS, at least partially, no formal measures have been taken in Belgium, except for some Flemish local entities which apply IPSAS according to the "Besluit van de Vlaamse Regering betreffende de beleids-en beheerscyclus van de gemeenten, de provincies en de openbare centra voor mattschappelijk welzijn, 25 juin 2010, M.B. 10 juillet 2010", which is a decree at the basis of their policy and their management cycle.

Currently, we could say that, in Belgium, there is a will to modernize public accounting, and the reform of 2003 is the evidence, but IPSAS do not seem to interest public authorities. Indeed, the cost and the time needed, and the incomplete nature of these standards cannot justify their application, replacing the existing accrual accounting systems.

\section{Conclusion}

In this paper, we have focused on explaining the evolution of Belgian accounting by emphasizing the modifications brought by the reform of 2003. This indeed establishes a double-entry general accounting system based on transactions. This reform implicitly makes reference to IPSAS since the notion of general accounting is linked to these standards. We have then analyzed the current accounting situation at the different levels of the Belgian institutional pyramid. We have also noted important differences between government levels. Indeed, while the lowest levels have adopted measures to implement, at least to some extent, the accounting reform of 2003, it is not the case for regions, communities and the federal State. Afterwards, we have studied the level of implementation of IPSAS in the world, which has allowed us to emphasize the heterogeneity of national accounting systems in this field. The various factors encouraging the adoption of IPSAS, and in particular the desire to harmonize accounting, do not indeed have the same influence everywhere. The study we have carried out in Belgium and concerning the compliance with three IPSAS (1,6 and 22) which are particularly suitable to the public sector, has pointed out, firstly, the differences between government levels and, secondly, the extent of the efforts still to be made to comply with international standards.

This paper has the advantage of contextualizing the Belgian reform of 2003 by being based on a strong retrospective study. It enables us to visualize clearly the current accounting situation. It also offers the advantage of synthetizing several studies on the implementation of IPSAS at the international level. The originality of the article also lies in analyzing the compliance with three IPSAS, interesting for several reasons (relevance to the 
public sector and ESA 95 and the link with the current Belgian accounting legislation). However, it would be interesting, for further research, to systematically analyze all IPSAS and their adoption by Belgian public entities, which would provide a more global view of the current situation and enable us to draw more general conclusions. An article could also follow the implementation of the accounting reform and provide recommendations to leaders. Indeed, it seems essential to focus on the complete implementation by the different Belgian government levels of the reform of 2003, this being a prerequisite to compliance with IPSAS.

\section{References}

Amar, A., \& Berthier, L. (2008). Le Nouveau Management Public: Avantages et Limites. Revue Recemap, 13.

Benito, B., Brusca, I., \& Montesinos, V. (2007). L'harmonisation des systèmes gouvernementaux d'information financière: le rôle des IPSAS. Revue Internationale des Sciences Administratives, 73(2), 323-350. http://dx.doi.org/10.3917/risa.732.0323

Brusca, I., \& Condor, V. (2002). Towards the Harmonisation of Local Accounting Systems in the international

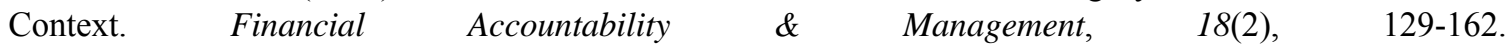
http://dx.doi.org/10.1111/1468-0408.00148

Carlin, T. M. (2005). Debating the Impact of Accrual Accounting and Reporting in the Public Sector. Financial Accountability \& Management, 21(3), 309-336. http://dx.doi.org/10.1111/j.0267-4424.2005.00223.x

Carvalho, J., Jorge, S., \& Fernandes, M. (2007). Conformity and Diversity of Accounting and Financial Reporting Practices in Portuguese Local Government. Canadian Journal of Administrative Sciences, 24(1), 2-14. http://dx.doi.org/10.1002/cjas.1

Christiaens, J., \& Van Den Berghe, M. (2006). The Ernst \& Young Guide to applying IPSAS. Die Keure.

Christiaens, J., Reyniers, B., \& Rollé, C. (2010). Les conséquences des IPSAS sur la réforme des systèmes d'information financière publique: étude comparative. Revue Internationale des Sciences Administratives, 76(3), 563-581. http://dx.doi.org/10.3917/risa.763.0563

Cour Des, C. (2001). Evaluation de la mise en œuvre de l'ordonnance de 21 novembre 2006 portant les dispositions applicables au budget, à la comptabilité et au contrôle. Rapport de la Cour des comptes transmis à l'Assemblée réunie de la Commission communautaire commune.

Des Robert, J. F., \& Colibert, J. (2008). Les normes IPSAS et le secteur public. Paris: Dunod.

Desille, S. (2009). L'apport d'une comptabilité générale dans le système de comptabilité des administrations: avantages et difficultés. Service Public Fédéral Finances-Belgique, Bulletin de Documentation, 69(1), 127-142.

FEE. (2007). Accrual Accounting in the Public Sector. Paper from the FEE Public Sector Committee.

Groot, T., \& Budding, T. (2008). New Public Management's Current Issues and Future Prospects. Financial Accountability \& Management, 24(1), 1-13. http://dx.doi.org/10.1111/j.1468-0408.2008.00440.x

IASB. (2010a). IPSAS 1-Presentation of financial statements.

IASB. (2010b). IPSAS 22-Disclosure of financial information about the general government sector.

IASB. (2010c). IPSAS 6-Consolidated and separate financial statements.

IFAC. (2003). Study 14: Transition to the Accrual Basis of Accounting: Guidance for Governments and Government Entities (2nd ed.). Public Sector Committee.

Institut des comptes nationaux-Banque nationale de Belgique. (2011). Comptes des administrations publiques 2010.

IPSASB. (2010). Consultation Paper: Conceptual Framework for general purpose financial reporting by public sector entities: role, authority and scope, objectives and users, qualitative characteristics and reporting entity.

Khoutra, D. (2007). La diffusion des normes comptables internationales pour le secteur public (IPSAS): le cas de Madagascar. Université Jean Moulin, Lyon 3.

Khrouz, F. (2007). Transparence des comptes et suivi des coûts. colloque Réutilisation des informations du secteur public, Solvay Business School.

Lüder, K., \& Jones, R. (2003). Reforming Governmental Accounting and Budgeting in Europe. Fachverlag Moderne Wirtschafts, Frankfurt am Main.

Müller, T., \& Berger, M. (2009). IPSAS explained: A Summary of International Public Sector Accounting 
Standards. Wiley.

OECD. (2002). Models of Public Budgeting and Accounting Reform. OECD Journal on Budgeting, 2(1). http://dx.doi.org/10.1787/budget-v2-sup1-en

Pina, V., \& Torres, L. (2003). Reshaping Public Sector Accounting: An International Comparative View. Canadian Journal of Administrative Sciences, 20(2), 334-350.

SPF Budget et Contrôle de la Gestion. (2009). Classification économique. Base Documentaire Générale.

SPF Personnel et Organisation. (2004). Copernicus-Au centre de l'avenir: La réforme de l'Administration fédérale belge.

Van Der Hoek, M. P. (2005). From Cash to Accrual Budgeting and Accounting in the Public Sector: the Dutch Experience. Public Budgeting \& Finance, 25(1), 32-45. http://dx.doi.org/10.1111/j.0275-1100.2005.00353.x

\section{Notes}

Note 1. Table inspired by Khrouz (2007), op. cit.

Note 2. For more information about the economic classification, see Service Public Fédéral Budget et Contrôle de la Gestion (2009), "Classification économique”, Base Documentaire Générale, 262 P., on www.begroting.be 